\section{A a}

\section{HOSPITAL PRACTICE, BRITISH AND FOREIGN.}

Nulla autem est alia pro certo noscendi via, nisi quamplurimas et morborum et dissectionum historias, tum aliornm tum proprias collectas habere, et inter se comparare.-MokgA De Sed. et Caus. Morb. lib. iv. Procemium.

\section{LONDON HOSPITAL.}

A CASE OF PELVIC FYDATLD FORMING A RETRO-UTERINT TUMOUR AXD CAUSING RTTENTION OF URINE.

\section{(Under the care of Dr. G. HERMAN.)}

THE formation of a hyclatid cyst in the pelvis is, fortunately, very rare, as Dr. Herman indicates in his remarks on this case. Davaine ${ }^{1}$ considered that they formed 7.9 per cent. of all cases, but it is probable that this estimate is far too high. The danger caused by their presence in this situation depends to a large extent on their pressure on the surrounding parts, especially on the urinary canals. In the female there are additional risks incurred from the obstruction to delivery caused in pregnant women. Porak ${ }^{3}$ collected a series of seventeen cases, in some of which delivery was impossible, Crsarean section was required, premature delivery was etfected, or the uterine contents were removed after emptying the cyst, \&c. No fewer than six died. In the cases recorded in this country the majority of patients appear to have been males, and attention has been drawn to the pelvic growth in consequence of difficulty in micturition or complete retention of urine, whilst in some there was evidence of pressure on the rectum also. Mr. Hurry Henwick, ${ }^{3}$ when recording a case before the Pathological Society, stated that he had found ninety cases of the disease recorded in the previous 200 years and added a careful analysis of them to his description of the case. The majority appear to have originated between the muscular coat of the bladder and the peritoneum. Mr. J. R. Lunnt recorded a case in the Transactions of the same society of somewhat similar character, and Mr. Fenwick ${ }^{5}$ had already brought forward another one. We have published various cases in the columns of THE LANCET ${ }^{6}$ and others are found in varions publications, ${ }^{\top}$ but the number of cases recorded in this country is not great. For the notes of the case we are indebted to Dr. IV. B. Butler, resident accoucheur, and Mr. C. L. Batteson, clinical clerk.

The patient, a woman aged sixty-six years, was admitted to hospital on July 30th, 1896. She had had two children, the last twenty-three years ago, and had ceased to menstruate at the age of forty-five years. She said that until her present illness she had always had good health. Her complaint was of difficulty in passing urine, especially on rising in the morning, and of pain before and during micturition. This had been present for about three months. On July 29 th she found herself unable to pass urine. She went to a medical man and had a catheter passed. Next day she found that she still could not pass urine and therefore she came to the hospital. When admitted she had been living in great poverty and was extremely thin. The veins on the surface of the abdomen were found to be prominent. There was a rounded swelling rising about half-way between the pubes and the umbilicus. By the vagina a large globular elastic swelling was felt behind the uterus. The cervix uteri was atrophied and pushed up behind the symphysis. The sound passed three and a quarter inches. The temperature was normal. The retro-uterine swelling seemed fixed. The patient continued to require the catheter until Aug. 7th, when she passed urine naturally. The physical signs indicated that the tumour was cystic. The far greater commonness of ovarian and broad ligament cysts as compared with other cysts led to the belief that it was one of these kinds. The absence of fever and the fact that the swelling did not diminish while the patient was at rest in bed eliminated

1 Entozoaires, 1877

2 Gazette Hebdomadaire de Médecine et de Chirurgie, p. 206, 1881 - Transactions of the Pathological Society. 1891, p. 213. 4 Ibid., p. 198 .
6 THE LANCET : Dr. Farre, Mr. Maunder, Mr. Bryant. 7 Mr. Quain: Medical Times and Gazette, vol, i., 1860, p. 495 . Wr.
Bond : Brit. Med. Jour, vol. i, 1891, p. 795 . encysted peritoneal dropsy. The rarity of pelvic hydatids, and especially of pelvic hydatid forming a single rounded swelling behind the uterus, prevented this condition from being suspected. On Aug. 11th the abdomen was opened. The tumour was found to be underneath the pelvic peritoneum. This was divided and immediately the hydatid membrane came into view. On manipulation it burst and clear yellow fluid escaped. The tumour consisted of one large cyst. It was removed and a Keith's drainage-tube put in the cavity where it had been. On microscopical examination of the fluid hooklets were found. The drainage-tube was removed the next morning. The subsequent course of the case showed that it would have been better to have left it in longer. On the following day the temperature rose, and it oscillated between $99^{\circ}$ and $101^{\circ} \mathrm{F}$. till Aug. 24th, when it went higher, and on the four following days reached nearly $103^{\circ}$. The patient was restless, but bad no other special symptom. On Aug. 29th examination by the vagina showed swelling behind the uterus. An exploring needle was put in and pus found. A large incision was therefore made and about a pint and a half of pus let out. After this the temperature at once fell and the patient steadily improved. The cavity was washed out daily. On Oct. 7 th the cavity had quite closed, and on Oct. 12th the patient went home well.

Remarks by Dr. HERMAN.-The above case is published because cases of hydatid tumour in the pelvis are rare. Freund, ${ }^{8}$ who practised for twenty-five years in Silesia, where the echinococcus is specially common, has only seen nineteen cases of pelvic hydatid tumours. I have only seen one case before. That one was in St. Bartholomew's Hospital, under the care of the late Dr. Matthews Duncan, and was, I believe, a hydatid of the omentum hanging down into Douglas's pouch and forming a tumour made of moveable nodules. A hydatic tumour like the one now reported, forming a single cyst, displacing the uterus forwards and causing retention of urine, is very rare, if it has been seen before. Its rarity is, I hope, sufficient excuse for the nonrecognition of its nature before operation. Could the diagnosis have been made it would have been better treat ment to have opened the swelling by the vagina. Pelvic hydatids, though rare, are important (1) on account of their tendency to suppurate, and (2) on account of their power of eroding and mining the pelvic bones, an account of which by Mr. Targett is contained in the last volume of the Obstetrical Transactions.

\section{SEAMEN'S BRANCH HOSPITAL, ALBERT DOCK, $\mathrm{E}$.}

A FATAL CASE OF SPINAL CONCUSSION ; NECROPSY. (Under the care of Mr. W. JoHNSON SMITH.)

As a rule concussion of the spinal cord is indicated after an injury to the spine by a temporary interference with the functions of the cord. It resembles in this respect concussion of the brain after injury to the head. This case is a very important one, as it shows that severe concussion of the cord may prove fatal without there being evidence after death of gross lesion. The absence of any gross lesion, such as bruising or even of ecchymosis of the substance of the cord, in a patient who died on the third day is most interesting, for it is not likely that hæmorrhage would have become absorbed at so early a date. Some years ago we published in THE LANCET the report of a case of concussion of the brain which proved fatal twelve days after an injury to the head. At the post-mortem examination the most careful search showed nothing abnormal, although the patient had been unconscious throughout after the receipt of the injury. The case was under the care of Mr. Sydney Jones, in St. Thomas's Hospital. For the notes of the case we are indebted to Mr. D. C. Rees, house surgeon.

A man aged forty-four years, a coal porter, was taken to the hospital at 3.30 A.M. on Aug. 27th, it being stated that while at work be bad fallen from a staging of a steamer into the hold of a coal barge beneath, a distance of twenty-fire feet. He was found lying on his back in an unconscious condition; he, however, regained consciousness in about eight minutes. On admission the patient was distinctly alcoholic; he was quite conscious and very talkative, and with a little help he sat up. His pulse was full, 80, and he 
had no symptoms whatever of collapse. He said he had lost the use of his legs and that be was suffering pain in the nape of his neck and back. He moved his arms quite well. The spine was examined, but no fracture, deformity, or tender areas could be discovered. The knee-jerks were lost. A catheter was passed and urine free from blood and albumin was drawn off. He had three superficial scalp wounds on the frontal region. No bleeding occurred from the nose, mouth, or ear. The pupils were of medium size, equal, and otherwise normal. At 10 A.M. his condition was quite altered from the one above described. He lay helplessly on his back. Respiration was solely diaphragmatic, his arms were flexed at the shoulderand elbow-joints, and his hands lay motionless on either side of his neck. He was now markedly collapsed. The pulse (112) was small and weak. The skin was cold and moist ; he was conscious, but dull and not easily roused. He smelt strongly of drink. There was complete motor paralysis of the legs, but no rigidity or spasms; the knee-jerks were absent, and the plantar reflexes were much increased and involuntary movements of the legs were most easily excited. Tactile and painful sensations were very defective and delayed ; it was impossible to say more on this point because his answers were unreliable and he seemed to guess. There was priapism, but no seminal discharge. There was retention of urine and the bowels had not acted. The cremasteric, hypogastric, epigastric, and scapular reflexes were all present. There was defective sensation on the trunk as high as the nipple in front and to the level of the inferior scapular angle (approximately) behind. No zone of hyperæsthesia was present and there were no pains, girdle or otherwise. There was complete motor paralysis of the arms with rigidity at the elbow- and shoulder-joints and marked spasm of the biceps in both arms. Sensation, as in the legs, was defective everywhere. There was no paralysis of the face, tongue, or neck muscles, but he kept the sternomastoids rather tense. He could flex, extend, and rotate the head without difficulty. None of the intercostal muscles moved and there was paralysis of the pectorals. The diaphragm worked excessively. There were a few scattered rhonchi to be heard in both lungs, this being a pretty constant condition in coal porters. The abdominal muscles were flaccid and it was impossible to get them into voluntary action. There was moderate distension. The spine was again examined, but with a negative result. There was no external bruising. No ocular paralysis was present and his vision was good in every field and the sympathetic was unaffected. The speech and voice were normal and no difficulty in swallowing fluids existed. On Aug.28th his condition had changed very little. The pulse was better, being 86 , and the skin was warm. His mental state had improved. The paralysis, \&c., remained quite unaltered. The bronchitis had increased and the smaller tubes were becoming involved; he was able to cough, but not with suficient force to expel mucus. Saline and stimulating expectorants and a steam tent were ordered. The temperature had risen to $101^{\circ} \mathrm{F}$. The catheter was being passed. On the 29 th he had very little sleep. The breathing was now laboured but regular, and the extremities were a little cyanosed. There was well-marked general bronchitis. The pulse was good, being 90 , the respiration was 38 , and the temperature was $100^{\circ}$. The only other change to be noted was that the rigidity of the biceps had passed off, but the paralysis had not ascended at all. He died one hour after this rather suddenly. Mr. Rees was unfortunately away, but suspected that the diaphragm must have become exhausted, as a good amount of air was entering the chest when he examined him for the last time.

Necropsy.-At the post-mortem examination, which was made twenty-four hours after death, no external bruising on the back was to be seen. The spinal column was exposed in the usual way and no fracture or dislocation was found. On the spinal canal being exposed no hæmorrhage was seen and the membranes appeared to be normal. The spinal cord was removed and carefully cut up, but no hæmorrhage into its substance could be detected. The brain was quite normal as was also the heart. The lungs showed evidence of extensive bronchitis and slight oedema at the bases. The liver was enlarged and showed early cirrhotic changes, but the kidneys were normal. No fracture of any bones was found.

Remarks $b$ y Mr. Rses. - The above notes are taken from a case which I think must be classed as one of spinal concussion, and as I have always been led to understand that it is one of great rarity $I$ thought it might prove of sufficient interest to be recorded, more especially as the case was under observation from its onset to the fatal termination. The special points of interest strike me as being the following:-(1) the marked delay in the supervention of the paralytic symptoms which one must attribute to the alcoholic condition of the patient at the time of the accident; (2) the close resemblance in the course and termination to hæmorrhage into the spinal canal; and (3) the absence of any gross lesion post mortem.

\section{Atledical Sorretics.}

\section{PATHOLOGICAL SOCIETY OF LONDON.}

Tumour of the Pulmonary Artery.-Two Cases of Paget's Disease of the Nipple.-Myxo-Sarcoma of the Colon.Multiple Polypi of the Small Intestine.-Revival of an Old Histological Method for Rapid Diagnosis.—Pulmonary Thrombosis in Typhoid Fever.-Keratinising Epithelial Tumours from the Scalp.

A MeEting of this society was held on Nov. 17th, Mr. H. T. Butisin, President, being in the chair.

Dr. T. H. SEQUEIRA showed a specimen of Tumour of the Pulmonary Artery obtained from a man aged thirty-seven years who died suddenly in the street while on his way to work. The specimen was obtained at the necropsy by Mr. Cuthbert Dixon of Hackney. The patient had suffered from dyspnca and cough for some months. The growth was in the wall of the pulmonary artery, being limited externally by the outer coat, while its inner surface was covered by the intima. It projected as a sessile poly poid mass $3.5 \mathrm{~cm}$. wide and $2 \mathrm{~cm}$. long into the lumen of the vessel. Its lower edge was one centimetre above the upper border of the semilunar valves. The tumour was so large that it must have been a very serious obstruction to the passage of blood through the artery. Microscopical sections of the growth showed a variety of cells. The bulk of the tumour was made up of large spindle-cells with oval nuclei. There were also numerous giant-cells and the perivascular spaces were crowded in some parts with small round cells. The endothelial lining of the vessel was intact. Parts of the growth had the appearance of having undergone myxomatous change. Certain portions of the sections, where the roundcells were numerous and the spindle-cells small looked as if the growth was inflammatory. The naked-eye and microscopical appearance suggested that the growth was a large spindle-celled sarcoma, in parts of which a myxomatous change has occurred. He commented on the rarity of primary tumours of the great vessels and quoted an instance of primary spindle - celled sarcoma of the upper part of the abdominal aorta, involving the diaphragm and pleura, described in 1875 by Bordowski. ${ }^{1}$ Dr. ChaRLES GreEN mentioned a specimen in the museum of the Royal College of Surgeons of Fugland which shows a tumour on the arch of the aorta. This specimen was obtained from a dog. The dog had during life suffered from attacks of dypsnoea; it had also a tumour on the right buttock. This was to have been removed, but the dog died under the anæesthetic. The tumour was found in the first part of the arch, but did not project into the aorta. The growth on microscopical examination presented the characters of a carcinoma. - The specimen shown by Dr. SEQUEIRA was referred to the Morbid Growths Committee.

Dr. A. A. KANTHACK and Mr. P. FuRNIVALL described a case of Primary Myxo-sarcoma of the Colon. The specimen was obtained from a lad aged seventeen years, and removed post-mortem from the region of the ascending colon. The striking feature was the colloid and myxomatous character of the growth, and such growths might be described as cylindromata, though Dr. Kanthack and Mr. Furnivall preferred the name myxo-sarcoma. Microscopically two elements were noticed: (1) the reticular tissue; and (2) cellular elements and the transition of the cellular structure with the reticular into either reticular tissue alone or cells alone.The PRESIDENT said that there were not many specimens of cylindroma described in the Transactions of the society. He had had the opportunity of examining one which occurred 